\title{
ANALYSIS OF POWER CONVERSION PROCESSES IN THE INDUCTIVE SWITCHING CIRCUIT FOR ALTERNATING- VOLTAGE CONTINUOUS AMPLITUDE-CONTROL
}

(Presented by E. Lippmaa)

\section{Introduction}

Improvement of output alternating-voltage and current waveforms in continuously controlled static converters has become an urgent problem in connection with recent wider use of such converters. In most cases the ideal waveform of input and output current is sinusoidal.

At the Institute of Thermophysics and Electrophysics of the Academy of Sciences of the Estonian SSR a technique for obtaining a continuously adjustable multistep sinewave-like voltage based on the use of an inductor operating as a controlled energy-storage device with its inductance varied by stepped switching of the number of its turns, has been elaborated.

Operation of corresponding switching controllers of alternatingvoltage amplitude is studied in detail in $\left[{ }^{1-1^{0}}\right]$.

The present paper deals with an analysis of power conversion processes in the controller under conditions of forced commutation.

\section{General discussion}

The circuit of the alternating-voltage amplitude controller is shown in Fig. 1. It is assumed that the circuit is fed with sinusoidal voltage $u=U_{m} \sin \omega t$, the switches I-IV and $1 \ldots n$ are ideal, and the load is purely resistive. The energy-storage device consists of an inductor with stepwise changeable turn number and infinite inductance $L ; i_{L}$ denotes the current passing through the inductor and $u_{a b}$ the voltage across it. The input current $i$ and the load current $i_{R}$ have a multistep waveform with $i=i_{R}$. Number of steps in the output voltage and current multistep waveform equals to the number of the switches $1 \ldots n$.

Since the output voltage $u_{R}$ contains higher-harmonic components, its fundamental harmonic amplitude is smaller than that of the supply voltage $\left(U_{R(1) m}<U_{m}\right)$ even for $\alpha=0$, where $\alpha$ is the angle at which the switches I, II or III, IV commence to conduct. The value of $U_{R(1) m}$ depends on the controlling angle $\alpha$ and the number of steps $n$. It has been found that $u_{R}$ contains odd higher harmonics of the order of $m=$ $=4 n k \pm 1$, where $k=1,2,3 \ldots$. 


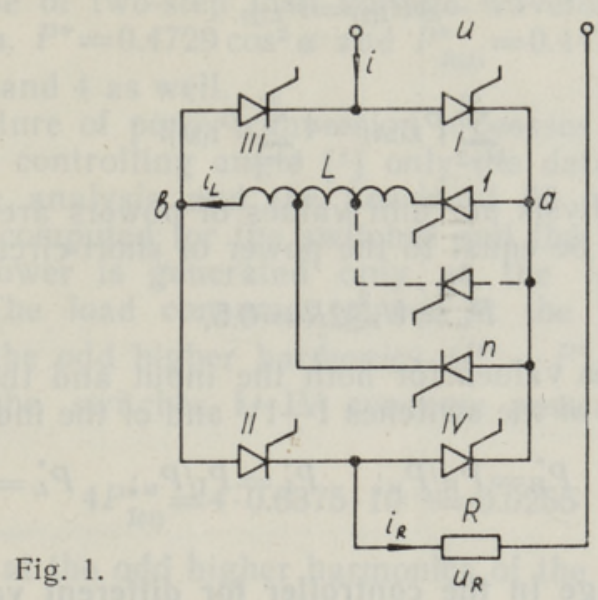

Since the circuit elements are assumed to be ideal, the input active power has to equal the load power $\left(P=P_{R}\right)$. Only active powers are regarded in this paper.

The input active power can be written as follows:

$$
P=U_{m} U_{R(1) m} \cos \alpha / 2 R \text {. }
$$

The load power at the fundamental harmonic may be expressed as

$$
P_{R(1)}=U_{R(1) m}^{2} / R \text {. }
$$

The input power is generated only at the fundamental harmonic, the load consumes power at the fundamental and the odd higher harmonics

$$
P_{R}=P_{R(1)}+\sum_{R=1}^{\infty} P_{R(4 n k \pm 1)}
$$

The switches I-IV consume power at the fundamental harmonic and generate it at the odd higher harmonics

$$
P_{\mathrm{I}(1)}=-\sum_{k=1}^{\infty} P_{\mathrm{I}(4 n k \pm 1)} \text {. }
$$

The power generated in the switches is consumed in the load:

$$
-4 \sum_{k=1}^{\infty} P_{\mathrm{I}(4 n k \pm 1)}=\sum_{k=1}^{\infty} P_{R\left(4 n_{k} \pm 1\right)}
$$

In addition to the described processes for $1<n<\infty$, energy exchange between the switches and the inductor takes place. The switches consume power at even higher harmonics and generate it at the second one

$$
\sum_{k=2}^{\infty} P_{\mathrm{I}(2 k)}=-P_{\mathrm{I}(2)} \text {. }
$$

On the other hand, the inductor generates power at the same even harmonics and consumes it at the second one

$$
P_{L(2)}=-\sum_{k=2}^{\infty} P_{L(2 k)}
$$

The power generated in the switches is consumed in the inductor 


$$
-4 P_{\mathrm{I}(2)}=P_{L(2)}
$$

and vice versa

$$
-\sum_{k=2}^{\infty} P_{L(2 k)}=4 \sum_{k=2}^{\infty} P_{\mathrm{I}(2 k)}
$$

In the further analysis per unit values of powers are used. Assuming the unit power $P_{u}$ to be equal to the power of short-circuit controller

$$
P_{u}=U_{m}^{2} / 2 R=0.5,
$$

one can find per unit values for both the input and the load power as well as for the power of the switches I-IV and of the inductor:

$$
P^{*}=P / P_{u} ; \quad P_{R}^{*}=P_{R} / P_{u} ; \quad P_{\mathrm{I}}^{*}=P_{\mathrm{I}} / P_{u} ; \quad P_{L}^{*}=P_{L} / P_{u} .
$$

\section{Energy exchange in the controller for different values of $n$}

a) $n=1$. For one-step load voltage waveform (Fig. 2) $U_{R(1) m}=$ $=0.8106 U_{m} \cos \alpha$. Per unit values of the input power and of the load power at the fundamental harmonic are found to be

$$
\begin{aligned}
P^{*} & =0.4053 \cos ^{2} \alpha, \\
P_{R(1)}^{*} & =0.3285 \cos ^{2} \alpha .
\end{aligned}
$$

The curves $P^{*}$ and $P_{R(1)}^{*}$ for $n=1$ versus $\alpha$ are shown in Fig. 3 and 4 .

For $n=1$, the switch 1 is on continuously.
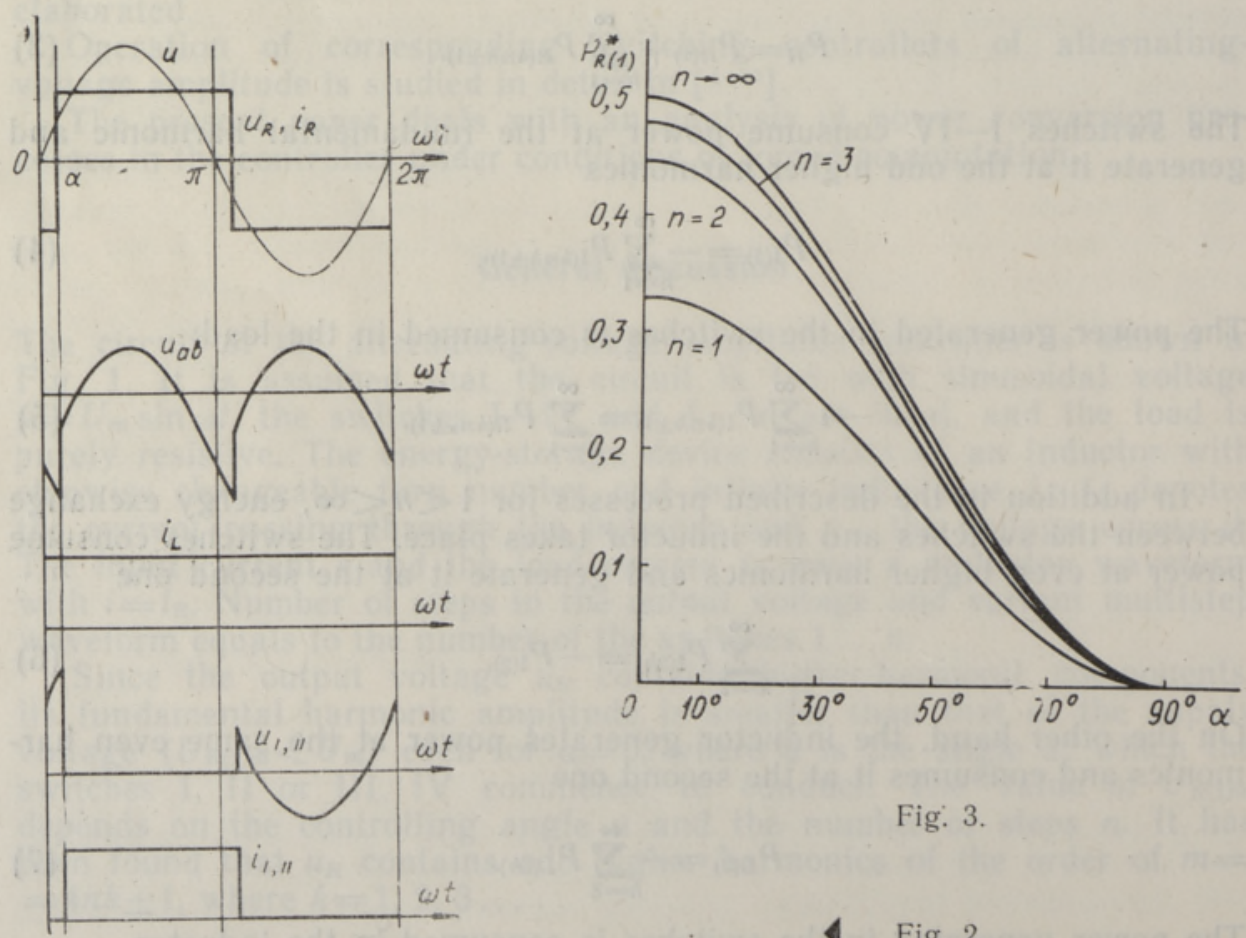

Fig. 3.

4 Fig. 2. 
b) $n=2$. In case of two-step load voltage waveform (Fig. 5) $U_{R(1) m}=$ $=0.9459 U_{m} \cos \alpha . P^{*}=0.4729 \cos ^{2} \alpha$ and $P_{R(1)}^{*}=0.4474 \cos ^{2} \alpha$ versus $\alpha$ are shown in Fig. 3 and 4 as well.

Since the nature of power conversion processes does not depend on the value of the controlling angle $\left[{ }^{1}\right]$ only the data for $\alpha=0$ have been regarded in the analysis and the power of 60 harmonics of Fourier' series has been computed for the switches and the load.

The input power is generated only at the fundamental harmonic $\left(P^{*}=0.4729\right)$. The load consumes power at the fundamental $\left(P_{R(1)}^{*}=\right.$ $=0.4474)$ and the odd higher harmonics $\left(P^{*}-P_{R(1)}^{*}=0.0255\right)$. We have obtained that the switches I-IV consume power at the fundamental harmonic

$$
4 P_{\mathrm{I}(1)}^{*}=4 \cdot 0.6375 \cdot 10^{-2}=0.0255
$$

and generate it at the odd higher harmonics of the order of $(8 k \pm 1)$

$$
-4 \sum_{k=1}^{7} P_{\mathrm{I}(8 k \pm 1)}^{*}=4 \cdot 0.5456 \cdot 10^{-2}=0.2182 \cdot 10^{-1} \text {. }
$$

The power of 60 harmonics in the load becomes

$$
P_{R(1)}^{*}+\sum_{k=1}^{7} P_{R(8 k \pm 1)}^{*}=0.4474+0.2182 \cdot 10^{-1}=0.4692 .
$$

For $n=2$, the current and voltage waveforms of the switches I-IV contain odd and even higher harmonics. The voltage and current of the

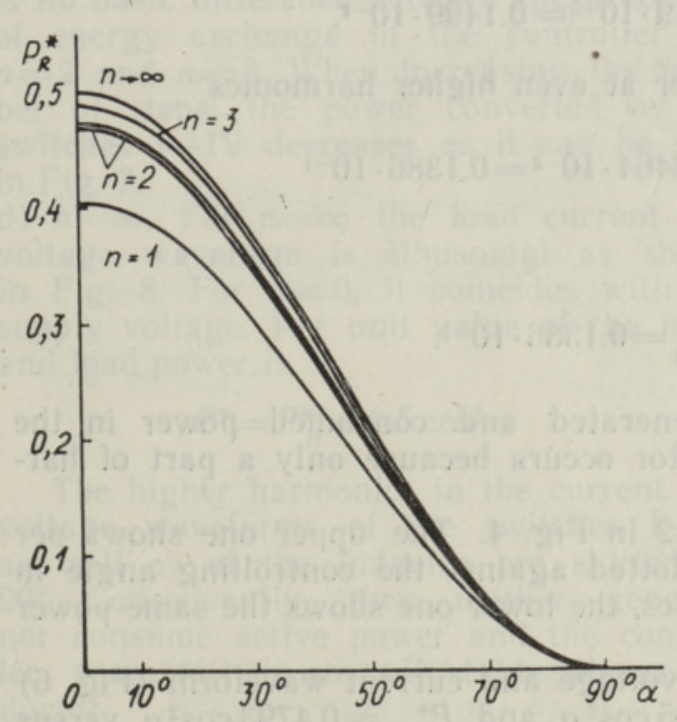

Fig. 4.

Fig. 5 .

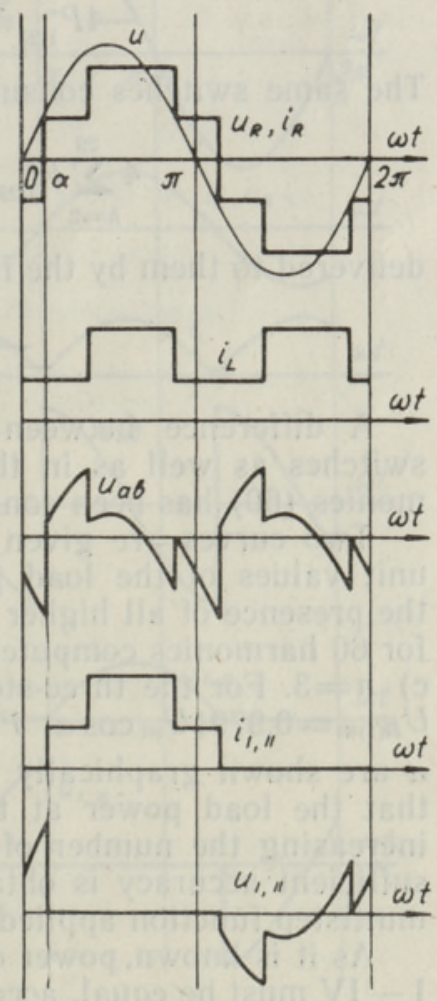



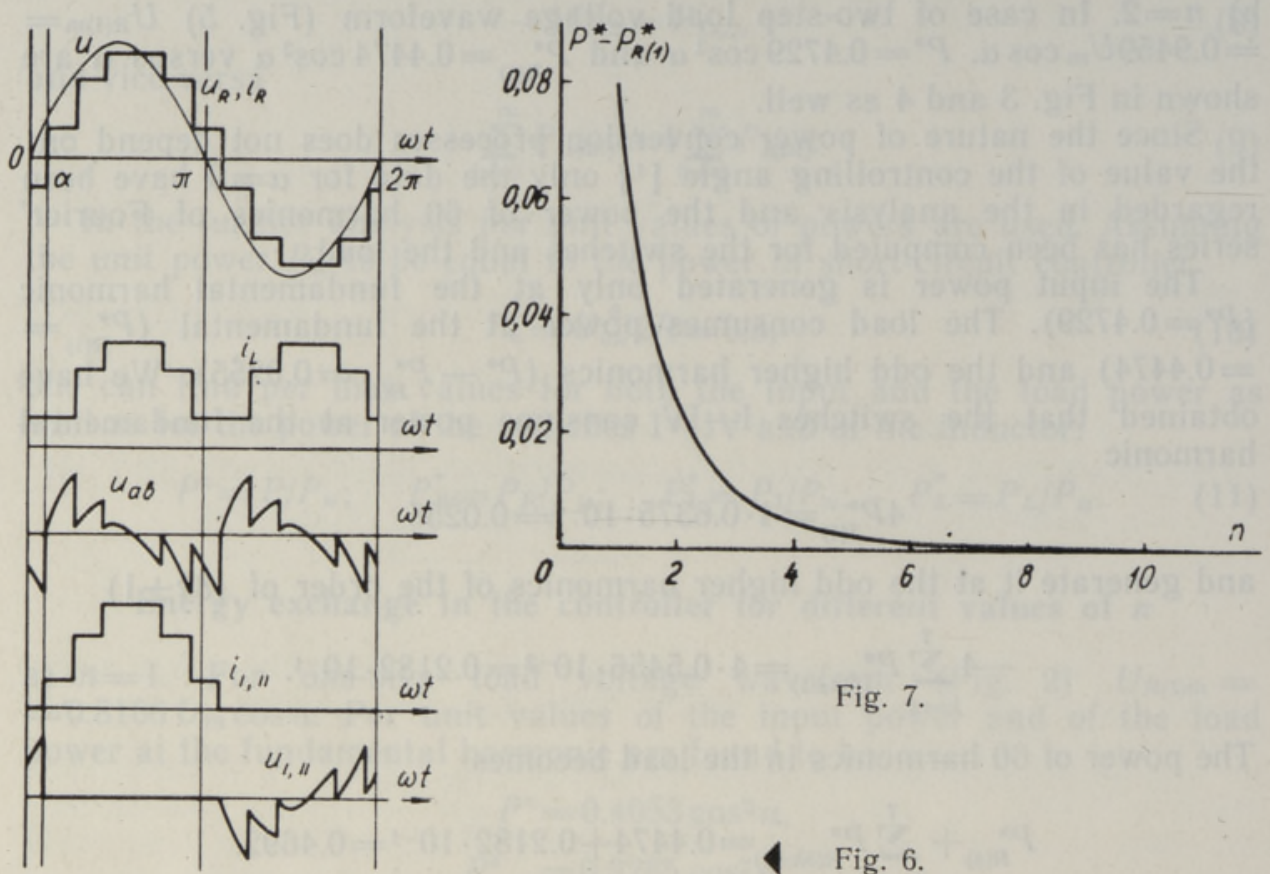

Fig. 7 .

inductor involve only even harmonics. It has been computed that the inductor consumes power at the second harmonic $P_{L(2)}^{*}=0.1499 \cdot 10^{-1}$ delivered to it by the switches I-IV

$$
-4 P_{\mathrm{I}(2)}^{*}=4 \cdot 0.3749 \cdot 10^{-2}=0.1499 \cdot 10^{-1} .
$$

The same switches consume power at even higher harmonics

$$
4 \sum_{k=2}^{29} P_{\mathrm{I}(2 k)}^{*}=4 \cdot 0.3464 \cdot 10^{-2}=0.1386 \cdot 10^{-1}
$$

delivered to them by the inductor

$$
-\sum_{k=2}^{29} P_{L(2 k)}^{*}=0.1386 \cdot 10^{-1}
$$

A difference between the generated and consumed power in the switches as well as in the inductor occurs because only a part of harmonics $(60)$ has been considered.

Two curves are given for $n=2$ in Fig. 4. The upper one shows per unit values of the load power plotted against the controlling angle in the presence of all higher harmonics, the lower one shows the same power for 60 harmonics computed.

c) $n=3$. For the three-step load voltage and current waveform (Fig. 6) $U_{R(1) m}=0.9791 U_{m} \cos \alpha . P^{*}=0.4895 \cos ^{2} \alpha$ and $P_{R(1)}^{*}=0.4793 \cos ^{2} \alpha$ versus $\alpha$ are shown graphically in Fig. 3 and 4. Fig. 3 as well as Fig. 7 show that the load power at the fundamental harmonic grows rapidly when increasing the number of steps. As it can be seen from Fig. 4 and 7 , a sufficient accuracy is obtained for the approximation of sinewave by the multistep function applied when $n \geqslant 3$.

As it is known, power consumption and generation in the ideal switches I - IV must be equal, arcordingly: 


$$
\begin{gathered}
4 P_{\mathrm{I}(1)}^{*}=4 \cdot 0.2555 \cdot 10^{-2}=0.1022 \cdot 10^{-1}, \\
-4 \sum_{k=1}^{5} P_{\mathrm{I}(12 k \pm 1)}^{*}=4 \cdot 0.2416 \cdot 10^{-2}=0.9664 \cdot 10^{-2} .
\end{gathered}
$$

The difference is given by the higher harmonics with the order of over 60 .

The load power is found to be

$$
P_{R(1)}^{*}+\sum_{k=1}^{5} P_{R(12 k \pm 1)}^{*}=0.4793+0.9664 \cdot 10^{-2}=0.4889
$$

The power consumed in the inductor $P_{L(2)}^{*}=0.7493 \cdot 10^{-2}$ is delivered to it by the switches:

$$
-4 P_{\mathrm{I}(2)}^{*}=0.1877 \cdot 10^{-2}=0.7508 \cdot 10^{-2}
$$

and the power consumed in the switches

$$
4 \sum_{k=2}^{29} P_{\mathrm{I}(2 k)}^{*}=4 \cdot 0.1664 \cdot 10^{-4}=0.6644 \cdot 10^{-2}
$$

is delivered to them by the inductor:

$$
-\sum_{k=2}^{29} P_{L(2 k)}^{*}=0.6597 \cdot 10^{-2}
$$

The foregoing analysis shows that there is no basic difference between the processes of energy exchange in the controller for $n=2$ and $n=3$. When increasing the number of steps, the power converted by the switches I-IV decreases as it can be seen in Fig. 7.

d) $n=\infty$. For $n=\infty$ the load current and voltage waveform is sinusoidal as shown in Fig. 8. For $\alpha=0$, it coincides with the supply voltage. Per unit value of the input and load power is

$$
P^{*}=P_{R}^{*}=0.5 \cos ^{2} \alpha .
$$

The higher harmonics in the current and voltage waveforms of the switches I-IV as well as of the inductor are shifted by $90^{\circ}$. Consequently, they neither generate nor consume active power and the controller operates as an adjustable linear inductor.

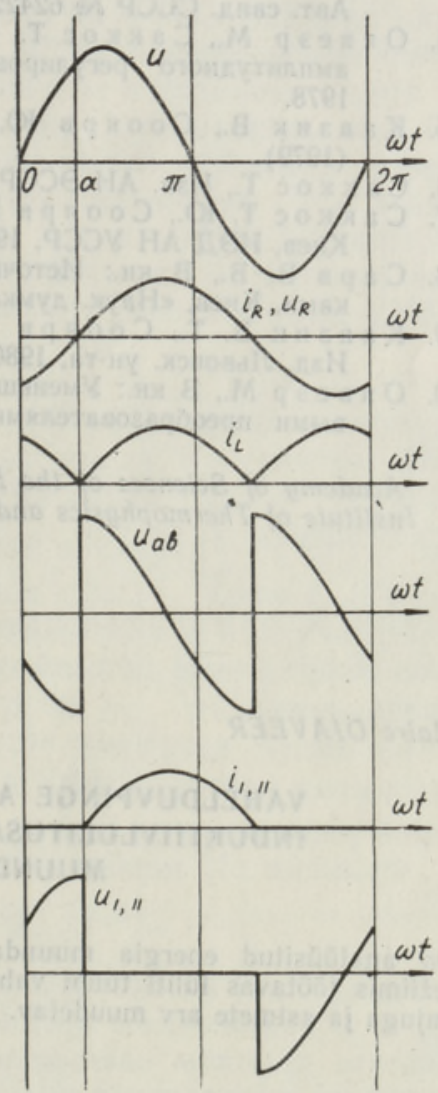




\section{Conclusions}

1. The nature of power conversion processes in the inductive switching circuit for alternating-voltage amplitude-control in conditions of forced commutation depends neither on the number of steps in the output voltage waveform nor on the value of the controlling angle.

2. The load consumes power at the fundamental and the odd higher harmonics. The power at the fundamental harmonic is delivered to it by alternating-voltage source, the power at the odd higher harmonics by the switches I - IV.

3. The switches I-IV operate as frequency converters, consuming power at the fundamental harmonic and generating it at the odd higher harmonics.

4. If $1<n<\infty$, power transmission at even harmonics between the switches I - IV and the inductor takes place.

5. For $n=\infty$, the circuit operates as a controlled linear inductor.

6. Practically, for obtaining sinewave-like output voltage $n=3$ is sufficient.

\section{REFERENCES}

1. О явеэр М., С а р в В., Изв. АН ЭССР, Физ. Матем., 26, № 3, $297-303$ (1977).

2. Оя в еэ р М., С а в в В., Изв. АН ЭССР, Физ. Матем., 27, № 3, 342-348 (1978).

3. С а рв В. В., Бат а р н Г. Л., О я в э р М. Р., С аккос Т. Ю., Х а с ен М. Я., Авт. свид. СССР № 624220, Бюлл. изобр., № 34 (1978).

4. О я в еэ р М., С а к к с Т., С а р в В., Вентильно-индуктивные цепи непрерывного амплитудного регулирования переменного напряжения, Таллин, «Валгус», 1978.

5. К а зи к В., Сооярв Ю., Изв. АН ЭССР, Физ. Матем., 28, № 4, 352-358 (1979).

6. С а к кос Т., Изв. АН ЭССР, Физ. Матем., 28, № 4, 346-351 (1979).

7. С аккос Т. Ю., Сооя р в Ю. Э., В кн.: Проблемы преобразовательной техники, Киев, ИЭД АН УССР, 1979, с. $62-65$.

8. С а р в В. В., В кн.: Источники электропитания со специальными характеристиками, Киев, «Наук. думка», 1979, с. $109-113$.

9. К а азик В. Т., Сооя рв Ю. Э., В кн.: Теоретическая электротехника, Львов, Изд. Львовск. ун-та, 1980 , с. $87-96$.

10. О я в еэ р М., В кн.: Уменьшение искажений в цепях с силовыми полупроводниковыми преобразователями, Таллин, ИТЭФ АН ЭССР, 1981 , с. $50-53$.

Academy of Sciences of the Estonian SSR,

Institute of Thermophysics and Electrophysics

Received

March 20, 1981

Maire OJAVEER

\section{VAHELDUVPINGE AMPLITUUDI SUJUVALT REGULEERIVAS INDUKTIIVLULITUSAHELAS TOIMUVATE ENERGEETILISTE MUUNDUSPROTSESSIDE ANALOUS}

On analüüsitud energia muundamist ja ülekannet ühefaasilises sundkommutatsioonirežiimis töötavas lülití tüüpi vahelduvpingeregulaatoris, mille väljundpinge on astmelise kujuga ja astmete arv muudetav. 


\section{Maŭpe $О Я В Е Э Р$}

\section{АНАЛИЗ ПРОЦЕССОВ ПРЕОБРАЗОВАНИЯ И ОБМЕНА ЭНЕРГИИ В ИНДУКТИВНО-КЛЮЧЕВОИ ЦЕПИ НЕПРЕРЫВНОГО АМПЛИТУДНОГО РЕГУЛИРОВАНИЯ ПЕРЕМЕННОГО НАПРЯЖЕНИЯ}

Анализируются процессы преобразования энергии в однофазном ключевом регуляторе переменного напряжения в режиме принудительной коммутации в случае ступенчатой формы выходного напряжения при различных значениях числа ступеней $n$.

Установлено, что характер обмена энергии в регуляторе не зависит ни от числа ступеней в форме выходного напряжения, ни от угла управления. Нагрузка потребляет мощность как на основной, так и на высших нечетных гармониках. Ключи моста работают преобразователями частоты, потребляя мощность на первой гармонике и генерируя ее на высших гармониках. При $1<n<\infty$ происходит дополнительный обмен энергии на четных гармониках между ключами моста и линейным дросселем. При $n=\infty$ ключи моста не участвуют в процессе преобразования энергии и регулятпр работает как линейный управляемый дроссель. 